\title{
Astronomy and Local Culture Dialectics; Kiai Muhammad Șāliḥ Darat's Idea in the Integration of the Hijriyah Calender
}

\author{
Muhamad Zainal Mawahib ${ }^{\mathbf{1}}$, Maskur Rosyid ${ }^{2}$, Muhammad Syarif Hidayat ${ }^{\mathbf{3}}$ \\ 1,2,3Fakultas Syariah UIN Walisongo Semarang \\ 1zainalmawahib@walisongo.ac.id,2masykurxrejo@walisongo.ac.id, \\ ${ }^{3}$ muhammadsyarif@walisongo.ac.id
}

\begin{abstract}
This paper aims to trace the genealogy of Kiai Sălih Darat in the field of falak sciences and the approach he used in uniting the differences in the initial determination of Ramadan in Semarang. This study is important, considering that Kiai Șālih Darat is more an expert in the field of Sufism. On the other hand, Kiai Șālih Darat was also positioned as an early generation of falak Indonesian expert (salaf). This paper includes a historical study that conducts critical analysis of data that has been isolated from various literatures. The results of the study showed that the expertise of Kiai Sălih Darat in the field of falak knowledge was obtained when conducting scientific jouney for Semarang scholars to alHaramayn scholars. Kiai Sālih Darat initiated a deliberation to determine the beginning of the month of Ramadan. This discussion involved ulama, astronomer, habaib and umara in Kauman Mosque in Semarang. The idea of deliberation is aimed at eliminating differences in society in determining the beginning of fasting. The idea of the initial unification of Ramadlan through deliberation was the substance of the Dugderan Tradition in Semarang, Central Java.
\end{abstract}

Keyword: Kiai Ṣāliḥ Darat, genealogy, islamic astronomy, local culture

[]

Tulisan ini bertujuan untuk menelusuri geneologi kelimuan Kiai Sālih Darat dalam bidang Ilmu Falak dan pendekatan yang ia gunakan dalam menyatukan perbedaan penentuan awal Ramadlan di Semarang. Kajian ini menjadi penting, mengingat Kiai Șālih Darat lebih sebagai ahli dalam bidang tasawuf. Pada sisi lain, Kiai Șāliḥ Darat juga diposisikan sebagai ahli Falak Indonesia generasi awal (salaf). Tulisan ini termasuk kajian sejarah yang melakukan analisis kritis terhadap data-data yang sudah dikolasi dari berbagai literatur. Hasil kajian menunjukkan bahwa keahlian Kiai Șālih Darat dalam bidang ilmu falak diperoleh ketika melakukan rihlah ilmiah kepada ulama Semarang hingga ulama al-Haramayn. Kiai Șaliḥ Darat menggagas musyawarah untuk menentukan awal bulan Ramadlan. Musyawarah ini melibatkan para ulama, ahli falak, habaib dan umara di Masjid Kauman Semarang. Gagasan musyawarah dilakukan bertujuan untuk menghilangkan perbedaan di masyarakat dalam menentukan permulaan puasa. Gagasan penyatuan awal Ramadlan melalui musyawarah ini merupakan substansi dari Tradisi Dugderan di Semarang, Jawa Tengah.

Keyword: Kiai Șāliḥ Darat, genealogi, falak, budaya lokal 
Muhamad Zainal Mawahib, Maskur Rosyid, Muhammad Syarif Hidayat

\section{Introduction}

KH. Muhammad Șāliḥ Darat al-Samārānī (Kiai Șaliḥ Darat) known as Mbah Sholeh Darat (1820-1903), was one of the great scholars of the Nusantara who lived around the 19th century. He became a teacher of scholars and figures in the indigenous lands, among the disciples of Kiai Sālih Darat, such as KH. Hāshim Ash'arī (Founder of Nahdlatul Ulama), KH. Ahmad Dahlān (Founder of Muhammadiyyah), and Raden Ajeng Kartini (Female Emancipation figure). ${ }^{1}$ Its popularity, especially in Semarang and its surroundings, still exists today. This can be seen from many pilgrims who make pilgrimages, especially during the hawl which is held every $10^{\text {th }}$ Shawwal at the Bergota Public Cemetery in Semarang. ${ }^{2}$

In the XIX century, Kiai Shalih Darat was one of the leading Indonesian scholars who wrote his religious ideas in the form of a "yellow book". ${ }^{3}$ In fact, according to Ghazali Munir's study, Kiai Șaliḥ Darat was the only author of the book in Java with Arabic letters (Arabic-speaking) printed and widely distributed, alongside KH Ahmad Rifa'ī Kalisalak (1786-1875) from Batang Central Java, is more senior, who has written a book with Arabic and Malay4, but printed and distributed on a limited basis.

The book "Sejarah dan Perjuangan Kyai Sholeh Darat Semarang " states that Kiai Ŝalih Darat has written at least 40 books. However, the Islamic ideas of Kiai Șālih Darat which can be found and found to date only amount to 14 books. ${ }^{5}$ Of all the works he produces, none uses Arabic, but instead uses Javanese and is written in Arabic-Javanese (Arabic-Pegon) letters. The uniqueness of the language used in these works, placing it as one of the pioneers of writing Javanese Islamic books and the only ulama in the late 19th century whose writings were in Javanese. In fact, the Tafsir Book entitled Faid al-Raḥmān fi Tarjamah Tafsii Kalam Mālik al-Dayyān, the work of Kiai Șālị

\footnotetext{
1Said Aqil Siraj, 'Kata Pengantar', in Syarah Hikam: KH. Sholeh Darat, Maha Guru Ulama Besar Nusantara, ed. Miftahul Ulum (Depok: Sahifa, 2016).

${ }^{2}$ Ghazali Munir, Tuhan, Manusia dan Alam dalam Pemikiran Kalam Muhammad Salih as-Samarani (Semarang: Rasail, 2008).

${ }^{3}$ Abdurrahman Wahid, 'Penelitian Kitab Kuning', Harian Kompas, 1982.

${ }^{4}$ Munir, Tuhan, Manusia dan Alam dalam Pemikiran Kalam Muhammad Salih asSamarani, 60.

5Munawir Aziz, 'Produksi Wacana Syiar Islam dalam Kitab Pegon Kiai Saleh Darat Semarang dan Kiai Bisri Musthofa Rembang', Afkaruna: Indonesian Interdisciplinary Journal of Islamic Studies 9, no. 2 (2017).
} 
Darat in the field of interpretation, is the first interpretation book in the archipelago written in Javanese with Arabic-Pegon script. ${ }^{6}$

The recent work of Kiai Saalih Darat has themed in various disciplines of Islamic religion, namely monotheism, tajwid, jurisprudence, interpretation, hadiths and poetry. ${ }^{7}$ This shows that he is better known as a Sufi. ${ }^{8}$ Depth in this field of science, Kiai Șāilị Darat, in the Shaykh Yāsīn al-Fadanī, is called alGhazālī al-Șaghīr (the little al-Ghazali). ${ }^{9}$

Kiai Șāliḥ Darat, although no writing was found in the field of astronomy, was positioned as a Falak Expert in Indonesia. At that time, the development of astronomy in Indonesia was very rapid. The first scholar known as an expert in Falak sciences at that time was Shaykh Tāhir Jalāluddīn al-Azhārī (1869-1957). this was proven by his work entitled "Pati Kiraan Pada Menentukan Waktu Shalat Lima yang Lima" (published in 1938) and Natijah al-Ummi The Almanac, Muslim and Christian Calender and Direction of Qibla According to Safie Sect (published in 1951). ${ }^{10}$

Susiknan Azhari in his writings also positioned Kiai Șālih Darat as one of the very influential figures in the development of Falak Science in Indonesia, in addition to Shaykh Aḥmad Khāțib Minangkabau (1855-1916), Ṭāhir Jalāluddīn al-Azhārī Al-Falakī, Aḥmad Rifa'ī Kalisalakak and Muḥammad Arshad AlBanjarī.11 This generation, by $\mathrm{H}$. Abd. Salam, is classified as an early generation (salaf) figure of Falak Science in Indonesia. While the later generation (khalaf) is Shaykh Jamīl Djambek, KH. Ahmad Daḥlān and continued by the next

\footnotetext{
6Mohammad Masrur, 'Kyai Soleh Darat, Faid Al-Rahman, dan RA. Kartini', AtTaqaddum 4, no. 1 (2016): 21-38, http://journal.walisongo.ac.id/index.php/ attaqaddum/article/view/725.

${ }^{7}$ Munir, Tuhan, Manusia dan Alam dalam Pemikiran Kalam Muhammad Salih asSamarani, 60.

${ }^{8}$ Akhmad Luthfi Aziz, 'Internalisasi Pemikiran KH. Muhammad Sholeh Darat di Komunitas Pecintanya: Perspektif Sosiologi Pengetahuan', Living Islam: Journal of Islamic Discourses 1, no. 2 (November 28, 2018), http://ejournal.uin-suka.ac.id/ ushuluddin/li/article/view/1733.

${ }^{9}$ Syaikh Muḥammad Yāsīn bin 'Īsā Al-Fadanī, Al-'Iqd Al-Farīd Min Al-Jawāhir AlAsānid, (Surabaya: Dār al-Saqaf, n.d.), 90.

${ }^{10}$ Susiknan Azhari, Ilmu Falak; Perjumpaan Khazanah Islam dan Sains Modern (Yogyakarta: Suara Muhammadiyah, 2007),10.

${ }^{11}$ Jayusman, 'Sejarah Perkembangan Ilmu Falak Sebuah Ilustrasi Paradoks Perkembangan Sains dalam Islam', Al-Marshad: Jurnal Astronomi Islam dan Ilmu-Ilmu Berkaitan 1, no. 1 (February 24, 2017); Susiknan Azhari, Ilmu Falak; Perjumpaan Khazanah Islam dan Sains Modern, 10.
} 
generation such as Sa'duddīn Djambek and Sirāj Daḥlān (1330-1398 H / 1911 1977 AD).12

Kiai Șālih Darat also played an important role in uniting the differences determining the beginning of the month of Ramadan in 1881 AD in Semarang during the Purbaningrat KRMT Regent. At that time, differences among Muslims in determining the beginning of Ramadan resulted in differences in other Islamic holidays, such as differences in Eid al-Fitr and Eid al-Adha. So that the Semarang Kauman Mosque held a trial to determine and unite the beginning of the month of Ramadan. ${ }^{13}$

Based on the description above, Kiai Sālih Darat, besides being known as a Sufism expert, is also positioned as an early generation Falak (salaf) figure in Indonesia. Therefore, this paper will explore the scientific geneology of Kiai Saalih Darat in the field of Falak Science. As for the steps taken is to examine the intersection of Kiai Saalih Darat with a network of scholars and teachers, especially those studying Falak Science. This paper is deepened with the idea of Kiai Sālih Darat in uniting the differences in the initial determination of Ramadan.

Through historical studies, this paper will critically analyze the data obtained from various literary sources. The verification process or often referred to as collation is done first before analyzing the data. ${ }^{14}$ This paper is directed to describe the intersection of Kiai Saalih Darat with a network of scholars and teachers in the field of Falak sciences. Besides it is also to understand the idea of Kiai Saalih Darat in terms of the initial unification of Ramadan in Semarang.

\section{Biography of Kiai Șāliḥ Darat}

The full name of Kiai Șālih Darat is Muhammad Șālih ibn 'Umar alSamārānī, born in Kedung Jumbleng Village, Mayong District, Jepara Regency, Central Java, around $1820 \mathrm{AD} / 1235 \mathrm{H} .{ }^{15}$ His year of birth coincided with the

${ }^{12}$ Abd. Salam, Dr. H. Sriyatin Shodiq, MA, Doktor 'Ilmu Falak'; Sebuah Apresiasi dari Seorang Senior, Teman dan Murid, 2012.

13Triyanto, Nur Rokhmat, and Mujiyono, 'Warak Ngendhog: Simbol Akulturasi Budaya pada Karya Seni Rupa', Komunitas: International Journal of Indonesian Society and Culture 5, no. 2 (February 18, 2014), 164.

${ }^{14}$ Sartono Kartodirdjo, 'Metode Penggunaan Bahan Dokumenter', in Metode-Metode Penelitian Masyarakat, ed. Koentjaraningrat (Jakarta: Gramedia, 1977), 83.

15Munir, Tuhan, Manusia dan Alam dalam Pemikiran Kalam Muhammad Salih asSamarani, 33. 
year of the birth of the charismatic cleric and became a teacher of scholars in Java-Madura, namely KH. Khalil Bangkalan (1235 H/1820 AD).16 Both of these figures are equally important references of Nusantara scholars before and after continuing their studies at Haramayn.

There are at least two reasons for the laqab (addition) of the name "Darat" after its name, that is, the first one itself is recognized by Kiai Șâlih Darat as it appears on the cover of his paper entitled "Sharh al-Barzanji" and also at the end of the letter addressed to the "Chief of Interpretation of the Anom, Head of the Surakarta Palace", inscribed "al-Ḥaqīr Muhammad Șālị Darat", as well as the phrase "Muhammad Șāih Ibn Umar Semarang Darat", as stated in the cover of his work "al-Murshìd al-Wajizz" and "Al-Mahabbah wa al-Mawaddah fi Tarjamah Qawl al-Burdah".17 Second, the "Darat" laqab is derived from the district name "Darat", a place near the northern coast of Semarang. The place was used as a place to land by people from outside Java. Currently entering the village of Dipah Darat or Tirto Darat, Dadapsari Village, North Semarang District, Semarang City, Central Java. ${ }^{18}$ Certainly the addition of a name like this, adding a place of residence or birth has become a custom for certain people.

Kiai Sălih Darat was the son of Kiai Umar, one of the warriors in the Java war (1825-1830 AD) and a confidant of Pangeran Diponegoro in the north coast of Java. Besides Kiai Umar, there is also Kiai Syada 'and Kiai Murtadla Semarang. ${ }^{19}$ While Nyai Umar, Kiai Șāih Darat's mother, according to a source from Agus Tiyanto (husband of Nyai Isnadiyah, a descendant of Kiai Șālih Darat who resides in Klaten, Central Java), who received information from Habib Luthfi Pekalongan, stated that Mrs. Kiai Șālị̣ Darat is still a descendant of Sunan Kudus or Shaykh Ja'far Șadīq, namely Nyai Umar bint Kiai Singapadon

16Mastuki HS dan Ishom El-Seha, Intelektualisme Pesantren (Jakarta: Diva Pustaka, 2004), 137.

${ }^{17}$ Munir, Tuhan, Manusia dan Alam dalam Pemikiran Kalam Muhammad Salih asSamarani, 34.

${ }^{18} \mathrm{Abu}$ Malikus Salih Dzahir, Sejarah dan Perjuangan Kyai Muhammad Shaleh Darat Semarang (Semarang: Panitia Haul Kyai Shaleh Darat Semarang, 2012); Aziz, 'Internalisasi Pemikiran KH. Muhammad Sholeh Darat di Komunitas Pecintanya: Perspektif Sosiologi Pengetahuan'; Munir, Tuhan, Manusia dan Alam dalam Pemikiran Kalam Muhammad Salih as-Samarani.

${ }^{19}$ Amirul Ulum, KH Muhammad Sholeh Darat Al-Samarani; Mahaguru Ulama Nusantara (Yogyakarta: Global Press, 2016), 37. 
(Panngeran Khațib) ibn Pengeran Qadīm ibn Pangeran Pelembang ibn Sunan Kudus. ${ }^{20}$

In literature, Kiai Șāliḥ Darat married three times. First, when he was still in Mecca, there were no sources explaining the name and origin of this first wife. From this marriage, a child named Ibrahim was born. He took this name in the preamble of his book, Tafsīr Fayḍ al-Rahmān fi Tarjamah Tafsìr Kalam Mālik al-Dayyān, namely Abū Ibrāhīm, Muḥammad Șāliḥ ibn Umar al-Samārānī. ${ }^{21}$

His second marriage was with Sofiyah, daughter of Kiai Murtadla Semarang, which took place in Semarang, when he returned from Mecca. From this marriage, he was blessed with two sons, Yahyā and Khalī. From his son's name, Yahyyā, he received the nickname Abū Yahyā. This is as stated in the book of Qabūl al-'Atāyā 'an Jawāb mā Șadara li al-Shaykh Abì Yahyaā. This book was authored by one of his disciples, Kiai Sha'ban bin Hasan Semarang to correct one part of the book of Majmu'ah al-Shar'iyyah by Kiai Șāih Darat. ${ }^{22}$ Whereas from Khalī's name, he had the additional name of Abū Khalīl, as stated in the cover of the book Fașalatan. ${ }^{23}$

Third, with Raden Ajeng Siti Aminah daughter of Sayyid 'Alī, daughter of Regent Bulus Purworejo. ${ }^{24}$ From this marriage he obtained one descendant, Siti Zahrah, edited by Kiai Aḥmad Daḥlān ibn 'Abdullāh al-Tarmāsī (d. 1329 H/ 1919 AD), one of the famous of Kiai Șālih's students who was experts in falak.25 He was the younger brother of Shaykh Mah̆ūz al-Tarmāsī (1868-1919 AD). After Kiai Aḥmad Daḥlān al-Tarmāsī died, Siti Zahrah was married to Kiai Amir Idris Pekalongan, the Founder of the Boarding School in Simbang Kulon (w. $1359 \mathrm{H} / 1939 \mathrm{AD}){ }^{26}$

Apart from Ibrāhīm, Yahyā, Khalīl and Siti Zahrah, there are 'Umar names that are probably sons of Kiai Șālih Darat. The data on the name of 'Umar ibn Saaliī al-Samārānī can be read in a collection compiled by Shaykh Yāsīn ibn 'Īsā

\footnotetext{
${ }^{20}$ Amirul Ulum, KH Muhammad Sholeh Darat Al-Samarani; Mahaguru Ulama Nusantara, 37.

${ }^{21}$ Aziz, 'Internalisasi Pemikiran KH. Muhammad Sholeh Darat di Komunitas Pecintanya: Perspektif Sosiologi Pengetahuan'.

22Ulum, KH Muhammad Sholeh Darat Al-Samarani; Mahaguru Ulama Nusantara, 37.

${ }^{23}$ Ghazali Munir, Tuhan, Manusia dan Alam dalam Pemikiran Kalam Muhammad Salih as-Samarani, 34 .

${ }^{24}$ Aziz Masyhuri, 99 Kyai Kharismatik Indonesia (Yogyakarta: Kutub, 2008), 66.

${ }^{25}$ Ghazali Munir, Tuhan, Manusia dan Alam dalam Pemikiran Kalam Muhammad Salih as-Samarani, 56.

26Ulum, KH Muhammad Sholeh Darat Al-Samarani; Mahaguru Ulama Nusantara, 46.
} 
al-Fadanī, a World Musnid from Padang, West Sumatra. For example, in the Shaykh Yāsīn al-Fadanī entitled al-Wāfi bi Dhayl Tadhkah al-Mashafí, it is mentioned:

"I (Shaykh Yāsīn ibn 'Īsā al-Fadanī) also read the book of Jamī' al-Ṣahịị by Imām al-Bukhārī of Kiai 'Abdul Muhịt ibn Ya'qūb Panji (son-in-law of Kiai Hāshim Ash'arī) of Sidoarjo-Surabaya, who lived in Mecca and a pious, more than a hundred years old, Sayyid 'Alī Ibn 'Alī al-Habshī al-Madanī. Both scholars recite the book from Kiai 'Umar ibn Șāih al-Samārānī and recount it from a long-time scholar, Shaykh 'Abd al-Ṣamad al-Falimbān̄̄."27

The biography of Kiai Umar ibn Salih al-Samārānī is very minimal. So it is not yet known who Kiai Umar ibn Salih really is, it might be another name from Kiai Șālih Darat or the name of one of the sons of Kiai Șālih Darat in Mecca. If he is the son of Kiai Salih, the question is which mother he was born from. This is something that cannot be answered, due to the lack of data. However, the name Kiai Umar Ibn al-Samārānī is widely mentioned in several books by Shaykh Yasin al-Fadani' ${ }^{28}$ and by Muhammad Mukhtāruddīn al-Falimbānī. ${ }^{29}$

\section{Kiai Șāliḥ Darat's Scientific Journey}

Kiai Șālih Darat was raised in a family that cared about education. Since childhood, he was equipped with the basic sciences of religion by his father and mother, especially reading the Qur'an and the knowledge of Tajweed. ${ }^{30}$ After that, he continued his religious studies in several Islamic boarding schools, both in Java and in the Haramayn, to the scholars.

As stated by Kiai Șālih Darat in full at the end of al-Murshīd al-Wajiżs book about his teachers, they are:

1. KH. M. Shahīd, Waturoyo, Kajen, Margoyoso, Pati, grandchildren of Kiai Mutamakkin, who lived during Pakubuwono II (1727-1749 AD). Kiai Șāliḥ Darat studied several books: Fatḥ al-Qarīb, Fatḥ alMu'īn, Minhaj al-Qawìm, Syarh al-Khațīb and Fatḥ al-Wahhāb.

\footnotetext{
${ }^{27}$ Syaikh Muhammad Yāsīn bin 'Īsā Al-Fadanī, Al-Wāfì Bi Dhayl Tadhkah Al-Mașhafí (Lebanon: Dār al-Bashīr, 2008), 5.

${ }^{28} \mathrm{Al}-\mathrm{Fadanī}$, Al-'Iqd Al-Farīd Min Al-Jawāhir Al-Asānid,66.

${ }^{29}$ Muhạmmad Mukhtāruddīn Al-Falimbānī, Bulūgh Al-Amānī (Beirut: Dār alDutaybah, 1988), 64.

30Munir, Tuhan, Manusia dan Alam dalam Pemikiran Kalam Muhammad Salih asSamarani, 36.
} 
2. KH. R. Muḥammad Șālih ibn Asnawī, a Sufi figure in Kudus. Kiai Șālih Darat studied the book of Tafsīr al-Jalālayn, the work of AlSuyūṭi and al-Mahallī.

3. Kiai Isḥāq, Damaran, Kudus. Kiai Șāliḥ Darat studied Naḥw and Sarfand Fath al-Wahhāb.

4. Kiai Abū 'Abdullāh Muhammad al-Hādī ibn Ba'ūnī, a mufti of Semarang. Kiai Șālih Darat learned about falak science.

5. Sayyid Shaykh ibn Aḥmad Bafaqih Bā'alawī in Semarang. Kiai Șāliḥ Darat studied Jawharah al-Tawhīd by Ibrāhīm al-Laqanī and Minhaj al-'Ābidīn by al-Ghazālī.

6. Shaykh 'Abd al-Ghānī Bima in Semarang. Kiai Șālih Darat learned Sittin Mas'ilah.

7. Haji Muhammad Irshād, Lowano, Begelan, Purworejo. Kiai Ṣāliḥ Darat learned the importance of science and maw'idah, then he revealed it in the form of Nazam. ${ }^{31}$

If you pay attention, some books which are studied by Kiai Șālih Darat are more dominated by the books that contain explanations, not basic books. So learning it takes quite a long time. Then it can be said that Kiai Șālih Darat has been able to read books before studying religion in Kudus, Pati, Purworejo and Semarang.

At the end of the $18^{\text {th }}$ century and early $19^{\text {th }}$ century, many students deepened their knowledge to Mecca which was the center of Islamic studies for most Indonesians. There, students can learn from Haramayn scholars, senior students, and international level. ${ }^{32}$ Kiai Șālih Darat, including a santri from Indonesia who was studying in Mecca, was estimated to depart in 1835 AD. 33

Kiai Sāalih Darat continued his studies in Mecca. He and his father went to Mecca to perform Hajj and study. On the way, they both stopped by for some time in Singapore. Here, Kiai 'Umar, Kiai Șālih Darat's father, had relatives, because Kiai 'Umar married a woman from Singapore who had a daughter

\footnotetext{
${ }^{31}$ Ghazali Munir, Tuhan, Manusia dan Alam dalam Pemikiran Kalam Muhammad Salih as-Samarani, 36-37.

${ }^{32}$ Karel A. Steenbrink, Pesantren Madrasah Sekolah Pendidikan Islam dalam Kurun Modern, ed. Karel A. Steenbrink and Abdurrahman (Jakarta: LP3S, 1991), 18.

33Dzahir, Sejarah dan Perjuangan Kyai Muhammad Shaleh Darat Semarang, 8.
} 
who was married to Kiai Muḥammad Hādī Giri Kusumo Mranggen, Demak. After arriving in Mecca, his father died. ${ }^{34}$

While in Mecca, Kiai Șālih Darat learned to several scholars, they are: 1) Shaykh Muḥammad al-Muqrī al-Mișrī al-Makkī, 2) Shaykh Muḥammad ibn Sulaymān Ḥasballāh, 3) Sayyid Aḥmad ibn Zaynī Daḥlān, mufti Shāfi'iyyah in Mecca (1231-1304 H/1817-1886 AD), 4) al-'Allāmah Aḥmad al-Naḥrawī alMișrī al-Makkī, 5) Sayyid Muḥammad Șāliḥ al-Zawawī al-Makkī, instructor at Masjīd al-Ḥaram 6 ) Kiai Zahīd, 7) Shaykh 'Umar al-Ṣāmī, 8) Shaykh alSanbulawī al-Miṣrī, 9) Shaykh Jamal, mufti Ḥanafī in Mecca. In Mecca, Kiai Șālị̣ Darat studied science of jurisprudence, interpretation and Sufism. ${ }^{35}$

Because of the depth of his knowledge, the ruler of the Hijāz at that time entered into a contract with Kiai Sālih Darat to teach in Mecca. Seeing the name of Kiai Șāliḥ Darat was increasingly soar in Mecca, his brother-in-law, Kiai Hādī Girikusumo who at that time was also studying in Mecca, had the desire to invite him to return to the Nusantara(home land). Because Kiai Șālị Darat was already bound by a contract, finally Kiai Girikusumo invited him to go home quietly. So that his tracks are not known, Kiai Șālih Darat was put in a chest. On the way there was news that Kiai Girikusumo had kidnapped one of the Mecca Shaykhs, Kiai Șālih Darat, so when the ship docked in the port of Singapore, Kiai Girikusumo was arrested and if he wanted to be free, he had to replace it with money as a fine. With this incident, Kiai Girikusumo's students and Kiai Umar's relatives held a meeting to raise funds. Finally, Kiai Girikusumo and Kiai Șāliḥ Darat succeeded in continuing their journey and landing in Java. ${ }^{36}$

As for Kiai Șălih Darat's work in the Nusantara, he once taught at the Pesantren Salatiyang located in Maron Village, Loano District, Purworejo. Then continue the study activities at the mosque established by the in-laws of Kiai Șallị Darat, Kiai Murtadla around the 1700s. In this Mushola, there are a lot of students who study the Koran and some determine, finally the pesantren was made a place to live. ${ }^{37}$ This is the forerunner of the Semarang Islamic Boarding School, which is listed as the second oldest Islamic boarding school in Semarang, after the Dondong Boarding School, Mangkang Wetan, Semarang,

\footnotetext{
34Ulum, KH Muhammad Sholeh Darat Al-Samarani; Mahaguru Ulama Nusantara, 43.

${ }^{35}$ Munir, Tuhan, Manusia dan Alam dalam Pemikiran Kalam Muhammad Salih asSamarani, 38-39.

36Dzahir, Sejarah dan Perjuangan Kyai Muhammad Shaleh Darat Semarang, 12.

37Ulum, KH Muhammad Sholeh Darat Al-Samarani; Mahaguru Ulama Nusantara, 50; Dzahir, Sejarah dan Perjuangan Kyai Muhammad Shaleh Darat Semarang, 17.
} 
which is estimated to have been established in 1629 AD. KH. Shāfi'i Piaranegara. ${ }^{38}$ According to historical records, in 1870, Kiai Șālị̣ Darat began to continue his Koranic activities at the mosque and grew up to become a place of residence for students, ${ }^{39}$ which later became known as "Pesantren Darat".

Regarding the existence of "Darat" Islamic Boarding School, KH Kiai Maimoen Zubair in his book Tarājim Mashāyikh al-Ma'āhid al-Dinniyyah bi Sarang al-Qudamā', said that Kiai Dahlān and Kiai 'Abd al-Shakūr had studied at a pesantren or ribațurtured by Kiai Șāiḥ Darat.

"After studying at Sarang (Rembang), Kiai Dahlān continued his studies at various boarding schools, including the Adipuro Blora Islamic Boarding School that was raised by Kiai Hamzah. In this Pesantren, he studied for two years. After that, he continued on to the "Darat" Pesantren Semarang for a year. Then he returned to Sarang." 40

"After completing his studies at Haramayn, Kiai 'Abd al-Shakūr continued his scientific journey to the city of Semarang, to study at Ribat (pesantren) which was cared for by a large ulama known as Sălih Darat Semarang. In this pesantren, he resides and studies various disciplines, he studies Kiai Sālih Darat, books of figh, Sufism, and interpretation. Kiai Sālih Darat was the last teacher visited by Kiai 'Abd al-Shakūr in studying religious knowledge. When it was one, two or three years, he wanted to return to his home. When asking permission from Kiai Saalih Darat, he is permitted to return to his hometown. Kiai Șālih Darat advised that Kiai 'Abd al-Shakūr would always spread the knowledge of the religion of Islam that was imbued during the Islamic Boarding School and made it a habit to read Tafsir al-Jalālayn and Ihyā' 'Ulìm al-Dīn by al-Ghazālī."41

Some of the literature above shows that the existence of "Darat" Islamic Boarding School is recognized and developed to produce many scholars and prominent figures in the Nusantara. ${ }^{42}$ This "Darat" Islamic Boarding School ended until the death of Kiai Șaliḥ Darat on Friday Legi, 28 Ramadan 1321 H/ 18 December $1903 \mathrm{AD},{ }^{43}$ the activities of the Islamic boarding school began to decline and during the Japanese occupation grew dim. Until finally, Kiai Amīr, one of the daughters-in-law who took care of the cottage, moved to

38 Dzahir, Sejarah dan Perjuangan Kyai Muhammad Shaleh Darat Semarang, 18.

${ }^{39}$ Dzahir, Sejarah dan Perjuangan Kyai Muhammad Shaleh Darat Semarang, 16-17.

${ }^{40} \mathrm{KH}$. Maimoen Zubair, Tarājim Mashāyikh Al-Ma'āhid Al-Dīniyyah Bi Sarang AlQudamā' (Rembang: Maktabah Al-Anwar, n.d.), 23.

41Zubair, Tarājim Mashāyikh Al-Ma'āhid Al-Dīniyyah Bi Sarang Al-Qudamā', 42.

${ }^{42}$ Munir, Tuhan, Manusia dan Alam dalam Pemikiran Kalam Muhammad Salih asSamarani, 56-58.

${ }^{43}$ Munir, Tuhan, Manusia dan Alam dalam Pemikiran Kalam Muhammad Salih asSamarani, 74-75. 
Kedungwuni-Pekalongan. ${ }^{44}$ Whereas Kiai Idrīs, a senior santri who helped teach students when Kiai Sālih Darat was sick to death, brought a number of santri to Solo, to revive the Jamsaren Islamic Boarding School, in 1904 AD.45 There was a haul memorial (commemoration of the anniversary which is held every year) every $10^{\text {th }}$ Shawwal, at the Semarang Bergota Tomb.

The legacy of Kiai Sālih Darat was only in the form of the books he had written. while the mosque made of wood in the form of houses on stilts has been damaged for a long time due to time and flooding with water. this is because the area of the mosque is located in North Semarang which often occurs flooding and tidal flooding. In 1993, Muhammad 'Alī Khalī bin Khalīl (d. 2010), one of the grandchildren of Kiai Șālih Darat, with all Kiai Șālị̣ Darat descendants built the mosque, which is now a permanent mosque. 46

\section{Kiai Saaliḥ Darat in the Falak Ulama Network in Java and al- Haramain}

In the $19^{\text {th }}$ century, the area of Mecca and Medina (al-Haramayn) in addition to being a place of spiritual pilgrimage, also became a center of growth and development of scientific traditions in the Islamic world. At this time, the leading Muslim scholars and scientists were born. The scientific geneology and ulama network in al-Ḥaramayn are well developed and continuous, including from Indonesia.

Their origin can be known from the place where the names are placed behind the names, such as 1) Aceh; al-Singkilī or al-Ashī, like Muhammad As'ad bin 'Abdullāh al-Faqīh al-Ashī, 2) Minangkabau; al-Minangkabawī or al-Fadanī, such as Ahmad Khațib al-Minangkabawī, 3) Mandailing; al-Mandahilī, such as 'Abd al-Qādir Ibn Șābir al-Mandahilī, 4) Malay South Sumatra; al-Falimbānī, such as 'Abd al-Ṣamad al-Falimbānī, 5) Jakarta; al-Batāwī, like Sayyid 'Uthmān bin 'Aqīl al-Batāwī, 6) Sundanese; al-Bantānī or al-Gharūtī, such as Nawawī alBantānī, 7) Java; al-Tarmāsī, al-Kādirī, al-Banyumasī, al-Samārānī, such as Maḥūz al-Tarmāsī, 8) Banjar; al-Banjarī, Muḥammad Arshad al-Banjarī, 9) Sambas; al-Sambasī, such as Ahmad Khațīb Sambas, 10) Bugis; al-Maqassarī,

${ }^{44}$ Dzahir, Sejarah dan Perjuangan Kyai Muhammad Shaleh Darat Semarang, 18.

${ }^{45}$ Munir, Tuhan, Manusia dan Alam dalam Pemikiran Kalam Muhammad Salih asSamarani, 58-59.

46Dzahir, Sejarah dan Perjuangan Kyai Muhammad Shaleh Darat Semarang, 28. 
like Yūsūf al-Maqassarī, 11) Malay Peninsula, al-Kalantanī, like Muhammad 'Alī al-Kalantanī, and 12) Patani; al-Fattānī, like Aḥmad al-Fattānī. 47

Abuddin Nata stated that in the nineteenth century intellectual traditions had developed, including the tradition of scientific rihlah, the tradition of pilgrimage, the tradition of reading, the tradition of memorization, the traditions of reading, writing, giving shrines, tahqiq and researching, and the tradition of collecting books and building libraries. ${ }^{48}$ Such an intellectual tradition that is also carried out by the Ulema of the Nusantara, began to do rihlah to al-Haramayn to write works and collect them.

This intellectual tradition developed in various scientific fields, including the field of Falak sciences. Khazanah Falak scholarship written by many scholars. For example, Shaykh Ahmmad Zaynī Daḥlān (1917-1886 AD) wrote a work in the field of Falak Science entitled al-Mukhtașar fi Ma'rifah al-Sinin wa al-Rub' al-Mushtahir, Shaykh Muhammad Mukhtār Bogor wrote the book Taqrīb al-Maqșid fi al-'Amal bi al-Rub' al-Mujayyab, and Shaykh Ahmad Khațīb al-Minangkabawī wrote Al-Jawāhir al-Naqiyah fi al-A'mal al-Jaybiyah (d. 1334 H / 1915 AD) supplemented with other works about science counting and measuring science with the titles Rawdah al-Hussāb fi' Ilm al-Hisāb, ${ }^{49}$ Mu'allam al-Hisāb fi IIm al-Hisāb and al-Natijah al-Mardiyyah fi Tahquìq al-Sunnah alShamsiyah wa al-Qamariyyah. ${ }^{50}$

Likewise in the study of falak sciences conducted by the scholars of alHaramayn. The book of falak which was studied by students in Mecca in the nineteenth century included several books, including (a) Risālah al-Maridinī wa al-Shalbī fi al-Falak, (b) Al-Taqrīrät al-Nafisah fi Bayān al-Basițah wa alKabisah, and (c) Al-Rub' al-Mujayyab (all three are the work of Ahmad ibn Muhammad al-Qasțalānī), (d) Al-Mukhtașar fi Ma'rifah al-Sininn wa al-Rub' alMushtahir, the work of Shaykh Ahmad Zaynī Dahlān (d. 1304 H), (e) AlJawāhir al-Naqiyah fi al-A'māl al-Jaybiyah, the work of Shaykh Aḥmad Khațīb al-Minangkabawī (d. 1334 H / 1916 AD), (f) Taqrīb al-Maqsîd fi al-'Amal bi alRub'al-Mujayyab, by Sheikh Muhammad Mukhtār bin Ațar al-Bughurī and (g)

\footnotetext{
${ }^{47}$ Azyumardi Azra, Historiografi Islam Kontemporer; Wacana, Aktualitas Dan Aktor Sejarah (Jakarta: Gramedia, 2002), 130.

${ }^{48}$ Abuddin Nata, Sejarah Sosial Inteletual Islam dan Institusi Pendidikannya (Jakarta: RajaGrafindo Persada, 2012), 155-157.

${ }^{49}$ Tim Penulis, Intelektualisme Pesantren: Potret Tokoh dan Cakrawala Pemikiran di Era Perkembangan Pesantren (Jakarta: Diva Pesantren, 2006), 68.

50Ulum, KH Muhammad Sholeh Darat Al-Samarani; Mahaguru Ulama Nusantara, 228.
} 
Majmū'ah Arba' Rasā'il Falak, by Khalīfah bin Ahmad al-Nabhānī. The ulama who taught Risālah al-Maridinī was Shaykh 'Abdurraḥmān al-Dahhān (w.1338 H / 1919 AD), Shaykh Khalīfah Ibn Hamīd al-Nabhānī taught Al-Taqrīrāt alNafisah along with the Risālah al-Maridinī. While al-Rub' al-Mujayyab was taught by Shaykh Ja'far al-Lubnī (d. 1340 H / 1921 AD). 51

Seeing the intellectual traditions and scientific meetings at al-Haramayn around the 19th century above, it was very possible for Kiai Sālih Darat to get falak teaching while studying in Mecca. There are strong indications that Kiai Șālih Darat learned from Shaykh Aḥmad ibn Zayni Daḥlān in the field of falak sciences. It is because Shaykh Ahmad ibn Zaynī Dahlān is also an expert in the field of falak science with his work Al-Mukhtașar fi Ma'rifah al-Sinin wa al-Rub' al-Mushtahir.

This is reinforced by the characteristics of scholars who taught in Mecca in that century as "encyclopedic scholars", scholars who mastered many disciplines. They teach many branches of science at scientific meetings,, such as monotheism, fiqh, interpretation, hadith, nahw, șarf and others. For example, Shaykh Muhammad Mukhtār Ibn Ațar, taught nậw, șarfand balāghah in the morning, the book of Ihyā' Ulüm al-Dīn in the afternoon and falak science on Tuesday. ${ }^{52}$

As has been written by Shaykh Maḥūz al-Tarmāsī (1868-1919) in the Preamble of the Kifāyah al-Mustafíd Limā 'alā min al-Asānid, ${ }^{53}$ said:

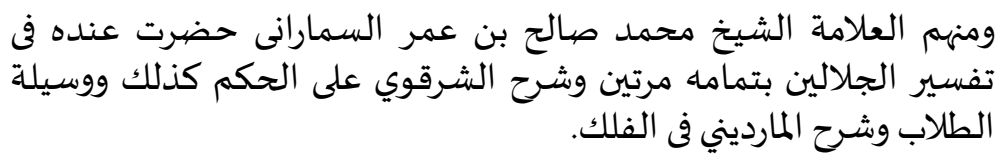

Meaning: "I studied with a very pious person, namely Shaykh Muhammad Șālịh ibn 'Umar al-Samārānī. I read to him the book of Tafsìr al-Jalālayn from the beginning to the end which was memorized twice and Syarh Hikam by Shaykh Al-Sharqawī, which was finished twice. I

51'Amal Ramaḍān 'Abd al-Ḥakīm Șiddīq, Al-Hayah Al-'Ilmiyyah Fī Makkah 1115-1334 H / 1703 - 1916 M (Mekah: Jam'iyyah Umm al-Qurā, 2006), 488.

${ }^{52}$ Ahmad Fauzi Ilyas, 'Tradisi Ilmiah Ulama Falak Haramian Akhir Abad 19 M dan Awal Abad 20 M (Profil Syaikh Muhammad Zein (W. 1388/1967) dan Kontribusinya dalam Ilmu Falak)', Al-Marshad: Jurnal Astronomi Islam dan Ilmu-Ilmu Berkaitan 1, no. 1 (2015).

53Syaikh Mahfūẓ Al-Tarmasī, Kifāyah Al-Mustafìd Limā 'alā Min Al-Asānid (Lebanon: Dār al-Bashā'ir al-Islāmiyah, n.d.), 7. 
Muhamad Zainal Mawahib, Maskur Rosyid, Muhammad Syarif Hidayat

also study the book Wasīlah al-Ṭullāb and the book Syarḥ al-Maridīnì in the study of falak science"

The statement above shows that Shaykh Mahfūz al-Tarmāsĩ is a student of Kiai Șālih Darat and one of the things he learned was falak science. Shaykh Maḥūz al-Tarmāsī became a pupil of Kiai Sālih Darat in the 1890s in Semarang, before going to Mecca for the second time and then he settled in Mecca. ${ }^{4}$ The books used at that time were the Book of Wasilah al-Tullāb Ii Ma'rifah al-Layl wa al-Nahār bi Tarīq al-Hisāb by Yahyā ibn Muhammad alHațāb and the Syarh Risālah al-Maridīni fi al-'Amal bi al-Rubu' al-Mujayyab by Ahmad ibn Ahmad al-Sunbatî. This book is an explanation (syarh) of the Book of Risks al-Maridīnī by Muhammad bin Aḥmad Badr al-Dīn al-Maridīnī. The three books of astronomy above are books published by Jami'ah al-Mulk Su'úd (Kind Saud University) in Mecca.

In addition, Kiai Sālih Darat's expertise in the field of Falak was also obtained from Kiai 'Abd al-Hādī ibn Ba'ūnī, a Mufti in Semarang. While Kiai 'Abd al-Hādī ibn Ba'ūnī studied falak with Kiai Muhammad Nūr al-Sepaton̄̄̄5 al-Samārānī. ${ }^{56}$ Even according to Muchoyyar HS's research, as quoted by Imroatul Munfaridah, that Kiai Sālih Darat also studied Falak under the guidance of Kiai Muhammad Nūr al-Sepatoni al-Samārānī. ${ }^{57}$ The students of Kiai Muhammad Nūr al-Sepatoni al-Samārānī who were of the same generation as Kiai 'Abd al-Hādī ibn Ba'ūnī were Kiai Shahīd al-Hajinī, Kiai Muḥammad Șāliḥ ibn Aswanī Kudus, and Kiai Isḥāq Pedamaran, Semarang. These four are Kiai Șāliḥ Darat's teachers. ${ }^{58}$

KH. Șālih Darat's expertise in Falak knowledge obtained in Java and alHaramayn has been inherited by two of his students, namely Kiai Ahmad Dahlān al-Tarmāsī (1862-1911 AD) Pacitan of East Java who became his sonin-law and Shaykh Ḥasan Asy'arī al-Baweanī al-Fasuruanī (1820-1921 AD,

\footnotetext{
${ }^{54}$ Munir, Tuhan, Manusia dan Alam dalam Pemikiran Kalam Muhammad Salih asSamarani, 88.

55"Al-Sepatoni" is an additional name attributed to the name of one of the villages in the north of Kauman Semarang Mosque. This village is located at Jalan Sepaton, an alley on Jalan Pemuda, Semarang

56Susiknan Azhari, Ensiklopedi Hisab Rukyat (Yogyakarta: Pustaka Pelajar, 2008), 192.

57Imroatul Munfaridah, 'Studi Kritik Terhadap Penentuan Arah Kiblat dan Awal Bulan Qamariyah Pemikiran KH. Ahmad Dahlan' (Institut Agama Islam Negeri Walisongo Semarang, 2011), 3.

58Ulum, KH Muhammad Sholeh Darat Al-Samarani; Mahaguru Ulama Nusantara, 64.
} 
born in Bawean Gresik and died in Pasuruan, East Java).59 Kiai Aḥmad Dahlān al-Tarmāsī wrote the book Tadhkirah al-Ikhwān ba'ḍ al-Rawā'ikh wa al-'Amal al-Falakiyyah, Natijah al-Mìqāt and Bulügh al-Wațar. While the work of Natijah al-Mīqāt was directed by Shaykh Iḥsan Jampes, Kediri (d. 1952 AD) with his book Tașrīh al-Ibārāt.60 While Shaykh Hasan Ash'arī compiled the book Muntahā Natā'ij al-Aqwāl and Jadwal al-Awqāt. Among the students of Shaykh Hasan Ash'arī known in the field of falak science, including KH. 'Abd al-Jalil Kudus the author of Fath Ra'üf al-Mannān and KH. Ma'șūm bin 'Alī alMaskumambangī Jombang the author of the book Badī'ah al-Mithāl fi Hisāb alSinin wa al-Hilāl and al-Durūs al-Falakiyyah. ${ }^{61}$

Expertise in the field of Falak sciences KH. Ma'șūm bin 'Alī alMaskumambangī was continued by his son-in-law, Kiai Mahfūz Anwār, the founder and leader of the Pesantren Paculwogang Jombang62 and KH Zubayr 'Umar al-Jaylānī and the author of al-Khulāsahah al-Wäfiyyah.63 While KH. 'Abd al-Jalil Kudus, the teacher from KH. Turaichan Adjhuri (maker of the Almanak Menara Kudus). KH. Turaichan has students who are experts in the field of Falak, KH. Noor Ahmad SS Jepara (author of the Book of Shams al-Hiläl, Tawfiq al-Raḥmān, Shawāriq al-Anwār and Nūr al-Anwār).64 KH Noor Aḥmad SS Jepara studied Falak Science to KH. Turaichan, KH 'Abd al-Jalī Ḥamīd Kudus, Shaykh Yāsīn al-Fadanī, KH. Zubayr Umar al-Jaylānī, Abdur Rachim (student of Sa'adoeddin Djambek and Kiai Misbachul Munir Magelang (student of $\mathrm{KH}$ Sulaiman Zuhdi, Nganjuk). Currently, Falak's expertise is inherited by Sayful Mujab, son of KH Noor Ahmad SS Jepara. Ahmad SS also had a student named

${ }^{59}$ Zainul Milal Bizawie, Masterpiece Islam Nusantara (Jakarta: Pustaka Kompas, 2016), 445.

${ }^{60}$ Bizawie, Masterpiece Islam Nusantara, 445.

${ }^{61}$ Masruroh, 'Studi Analisis Hisab Awal Bulan Kamariah Menurut KH. Muhammad Hasan Asy'ari dalam Kitab Muntaha Nataij Al-Aqwal' (Institute Agama Islam Negeri Walisongo Semarang, 2011), 45.

${ }^{62} \mathrm{M}$. Rifa Jamaluddin Nasir, 'Pemikiran Hisab KH. Ma'shum Bin Ali AlMaskumambangi (Analisis Terhadap Kitab Badi'ah Al-Misal Fi Hisab Al-Sinin Wa Al-Hilal Tentang Hisab Al-Hilal)' (IAIN Walisongo Semarang, 2010), 49.

${ }^{63}$ Maryani, 'Studi Analisis Metode Penentuan Waktu Salat dalam Kitab Ad-Durus AlFalakiyyah Karya Ma'sum Bin Ali' (IAIN Walisongo Semarang, 2010), 51.

64Jayusman, 'Pemikiran Ilmu Falak Kyai Noor Ahmad SS' (IAIN Walisongo Semarang, 2013), 7-8. 
Muhammad Khumaidi Jazry, Gresik (the author of al-Khulāșah fi al-Awqāt alShar'iyyah bi al-Lugharitmiyyah). ${ }^{65}$

As for the other students of Kiai Șāliḥ Darat are namely Shaykh Maḥūz alTarmāsī (1868-1919), ${ }^{66}$ KH Ahmad Dahlān (Founder of Muhammadiyah), KH. Sha'ban ibn Hasan Semarang (d. 1364 H/1946 AD). ${ }^{67}$ He even wrote an article entitled Qabūl al-'Atāyā 'an Jawāb mā Sada li Shaykh Abī Yahyāa, a correction to one part of the book Majmü'ah al-Shari'ah al-Kafiyah li al-'Awam by Kiai Șālih Darat. ${ }^{68}$ While other students who are well-known as Falak experts are Kiai 'Amīr Idrīs (son-in-law of Kiai Șālị̣ Darat) and R. Rahmat (grandson of Kiai Șāliḥ Darat). ${ }^{69}$

Kiai Șālih Darat's student who is an expert in other fields of Falak science is KH Țāhir - the successor of the Dondong Mangkang Wetan Islamic Boarding School, Semarang. KH Tāhir, the son of Kiai Abū Darda, was recorded as a teacher of Falak at the pesantren. ${ }^{70}$ Kiai Abū Darda is the son-in-law of Kiai Shāfi'i Piaranegara, the founder of the Dondong Islamic Boarding School. In this Dondong Islamic Boarding School, Kiai Șāliḥ Darat once studied with Kiai Abū Darda. $^{71}$

Thus, Kiai Șaliḥ Darat's expertise in the field of falak knowledge was gained during scientific rehearsals, both when studying at al-Haramayn and in Semarang. Although from a number of Kiai Șālih Darat's works that have been found, none of them discuss falak science, but this can be understood from some students who are experts in falak science. In addition, the expertise of Kiai Shalih's on falak knowledge can be seen from the idea of holding an initial Ramadan gathering in Semarang. The implementation of this deliberation is a substance of the Dugderan Tradition.

${ }^{65}$ Rizal Mubit, 'Hisab Awal Waktu Salat dalam Kitab "al-Khulashah Fi Al-Awqat AlSyar'iyyah Bi Al-Lugharitmiyyah" Karya Muhammad Khumaidi Jazry', Al-Marshad: Jurnal Astronomi Islam dan Ilmu-Ilmu Berkaitan 2, no. 1 (December 30, 2016): 64-82.

${ }^{66} \mathrm{Al}-\mathrm{Tarmasī,} \mathrm{Kifāyah} \mathrm{Al-Mustafíd} \mathrm{Limā} \mathrm{'alā} \mathrm{Min} \mathrm{Al-Asānid,} 7$.

${ }^{67}$ Azhari, Ensiklopedi Hisab Rukyat, 192; Munir, Tuhan, Manusia dan Alam dalam Pemikiran Kalam Muhammad Salih as-Samarani, 56.

${ }^{68}$ Munir, Tuhan, Manusia dan Alam dalam Pemikiran Kalam Muhammad Salih asSamarani, 57.

${ }^{69}$ Dzahir, Sejarah dan Perjuangan Kyai Muhammad Shaleh Darat Semarang, 19.

${ }^{70}$ Djawahir Muhammad, Semarang Sepanjang Jalan Kenangan, ed. Djawahir Muhammad (Semarang: Penerbit Aktor Studio, 1995), 195.

${ }^{71}$ Munir, Tuhan, Manusia dan Alam dalam Pemikiran Kalam Muhammad Salih asSamarani, 79. 


\section{KH Șālih Darat's Idea on the Initial Integration of Ramadan}

In the development of falak sciences in the "Nusantara", Kiai Șāliḥ Darat had contributed to the unification of the early lunation in Semarang. The idea of Kiai Sălih Darat was in the form of a deliberation on the initial determination of Ramadan and was announced to the people who had gathered at the Semarang square. Habits like this have become a tradition that still continues to this day, which is better known as the Dugderan Tradition which is carried out every time before Ramadan.

In $1881 \mathrm{AD}$, in the city of Semarang during the reign of Kiai Regent Raden Mas Tumenggung (KRMT) Purbaningrat, a tradition developed. This tradition takes the form of a Warak Ngendok procession in the square in front of the Kauman Semarang Mosque in order to welcome the coming of Ramadan. Semarang City people call this tradition as the term "Dugderan". At that time, after the Muslims performed the Asr prayer, exactly one day before Ramadan, the Bedug of Kauman Great Mosque was struck, followed by the ignition of the Cannon in the regency's courtyard in Kanjengan. Bedug made a "dug" sound and meriam made a "der" sound which many times was eventually combined into the term Dugderan..$^{72}$ This is done as a form of notification that tomorrow is the beginning of the month of Ramadan. That is the origin of the naming to this tradition.

At that time, the people of Semarang and its surroundings, there were differences in the determination of the beginning of the fasting month which led to differences in other Islamic holidays, such as Eid al-Fitr and Eid al-Adha. With the courage and intelligence of the Purbaningrat Regent, he made a policy to integrate various differences, one of which was the difference between the determination of the beginning of the month of Ramadan. The business of the Purbaningrat Regent was strongly supported by the ulemas in Semarang. One of the great scholars who gave many roles was Kiai Șālih Darat.73 Kiai Ṣālị̣ Darat as a very influential religious figure in Semarang at that time.

The purpose of the creation of the Dugderan tradition is to gather layers of society in an atmosphere of joy, mingling and greeting without difference. In addition, it can also be ascertained that the beginning of the month of Ramadan

\footnotetext{
72Edy Muspriyanto and Saifur, Semarang Tempo Doeloe; Meretas Masa (Semarang: Terang Publishing, 2007), 111-112.

${ }^{73}$ Supramono, 'Makna Warak Ngendog dalam Tradisi Ritual Dugderan di Kota Semarang' (Universitas Negeri Semarang, 2007). 65.
} 
is firm and simultaneous, as well as to provide an understanding that the initial determination of Ramadan is based on the Regent's agreement with the Imam of the Kauman Mosque in Semarang. So that unity is felt in the tradition that was created. 74

In the Dugderan Tradition, the role of Kiai Sālih Darat is as a party that provides reference or legality to the government and the community in determining the begining of fasting in the month of Ramadan. The main message to be conveyed through the tradition is to inform the people of Semarang when Ramadan starts fasting. This was done because of differences in the initial determination of Ramadan. This phenomenon inspired Kiai Șālih Darat to consult with the astronomers, scholars and habib experts in Semarang.

With Kiai Șalih Darat's expertise in the field of falak sciences then held a deliberation-the Isbat Congregation-. As far as the writer is searching, the idea of the Kiai Saalih Darat is the implementation of the initial isbat Session conducted by ulemas and falak experts in Indonesia. A deliberation to determine the beginning of Ramadan and eliminate differences. Thus it can be said that Kiai Șālih Darat is a pioneer of the isbat Session in Indonesia.

It appears that the Dugderan tradition was created to gather the people of Semarang and its surroundings. And so that people are interested, something unique is created, namely the art of Warak Ngendok. A handicraft in the form of an animal that is greedy and scary. The head consists of a sharp-toothed mouth, bulging eyes, erect ears or horns, long beard bushy. The body, neck and legs are covered with upside down feathers with alternating red, yellow, white, green and blue colors. There is a long, stiff curved hair like a body and there is a mane at the end. The shape of the egg or endhok is located between two hind legs. ${ }^{75}$ Warak Ngendok is made of wood, bamboo and coir.

When the community gathered, the beginning of the fasting information was conveyed by the government by reading the results of the deliberations of the habib, ulama and umara. It could be that the creation of Warak Ngendok was deliberately made in such a way that this tradition could not only be

\footnotetext{
${ }^{74}$ Supramono, 'Makna Warak Ngendog dalam Tradisi Ritual Dugderan di Kota Semarang', 66.

${ }^{75}$ Hamzah Sahal, 'Ihwal Warak Ngendok dan Dugderan', NU Online, last modified 2011, accessed December 27, 2019, https://www.nu.or.id/post/read/33261/ihwalwarak-ngendok-dan-dugderan.
} 
enjoyed by Muslims, but also the entire community. Because around the Kauman Mosque in Semarang is inhabited by a variety of ethnicities and religions.

Ethnic diversity from other countries is illustrated by the presence of Pacinan and Pedamaran settlements. This area is now around the Gang Pinggir road to Mataram road. This settlement was founded by immigrants from China during Admiral Chen Ho. There are also Malay Muslims who established settlements in Kampung Darat and Kampung Melayu. Likewise Arab, Indian, Pakistani and Persian Muslims who came to establish settlements in the Pakojan region. This area is around Kauman Street, Wahid Hasyim Street and Petek Street in Northern Semarang. ${ }^{76}$

Information about the beginning of fasting is also for non-Muslim communities in Semarang. Knowing that Muslims will fast, the non-Muslim community is indirectly invited to respect each other. It is because at that time, Semarang had become a modern city. Islam became a religion that was embraced by the majority of the people of Semarang, in the midst of the existence of other religions, such as Confucianism, Christianity (Protestantism and Catholicism), Hinduism and Buddhism. ${ }^{77}$ Even a meeting place for various social groups and various cultures. Therefore, it is not surprising that Semarang has diverse ethnicities and it is a place of social interaction in a pluralistic society.

Table: Population Distribution of Semarang City 1850-190078

\begin{tabular}{|c|l|c|c|c|}
\hline \multirow{2}{*}{ No } & \multirow{2}{*}{ Population Group } & \multicolumn{3}{|c|}{ Year } \\
\cline { 3 - 5 } & Bumiputera & $\mathbf{1 8 5 0}$ & $\mathbf{1 8 9 0}$ & $\mathbf{1 9 0 0}$ \\
\hline 1 & 20.000 & 53.974 & 70.426 \\
\hline 2 & Europe & 1.550 & 3.565 & 4.800 \\
\hline 3 & Chinese Foreign & 4.000 & 12.104 & 12.372 \\
\hline 4 & $\begin{array}{l}\text { Other } \\
\text { Easterners } \\
\text { Total }\end{array}$ & 27.400 & 1.543 & 1.688 \\
\hline \multicolumn{2}{|c|}{} & & 71.186 & 89.286 \\
\hline
\end{tabular}

${ }^{76}$ Supramono, 'Makna Warak Ngendog dalam Tradisi Ritual Dugderan di Kota Semarang', 50.

${ }^{77}$ Mukhamad Shokheh, Gerakan Keagamaan dan Perubahan Sosial; Dakwah Islam dan Misi Katolik Di Semarang 1890-194 (Pati: Kireinara, 2014),71.

${ }^{78}$ Shokheh, Gerakan Keagamaan dan Perubahan Sosial; Dakwah Islam dan Misi Katolik di Semarang 1890-194, 65. 
The idea of Kiai Saalih Darat in terms of the beginning of the month of Ramadan is conveyed through a cultural approach with regard to local cultural values. In this context, Kiai Șaliḥ Darat's movement strategy is taken by considering the social conditions of the community. Ijtihäd in deciding the beginning of the month of Ramadan was carried out through consultation with the government, ulama and habaib in Semarang and conveyed the results of the deliberation decisions with a cultural approach. Movement like this which is in M.C. Ricklefs as a modernism movement in Islam or modern Islam.79

Such strategies are also adopted by Kiai Șālih Darat when preaching. He did this by translating the book and writing it in Arabic-Pegon. Javanese intellectual works written by pegon by Kiai Șāih Darat in Semarang, at least show two important things in the da'wah movement strategy. A strategy that shows local values and is not a millennial movement. In this context, the preaching strategy of Kiai Șālih Darat sees the socio-culture of the Semarang people who generally do not master Arabic. ${ }^{80}$

Likewise what Kiai Șāliḥ Darat did in dealing with differences in the initial determination of Ramadan in Semarang. His ideas show that there is a modern Islamic intellectual tradition that is being built. $\mathrm{He}$ can be said to be a pioneer in the formation of the Dugderan tradition. The substance of this tradition is the submission of the results of the trial of the initial determination of Ramadan conducted by astronomers, scholars, haba'ib and the government. The aim is to unify the differences in the initial designation of Ramadan among the people. An idea which is the result of dialectics between falak science and the sociocultural community of Semarang. At that time, the social conditions of the people of Semarang had experienced differences in the initial determination of Ramadlan to have an impact on differences in the determination of the Eid alFitr. This can be traced from the process when Kiai Șaliḥ Darat studied in several places in Java, and when he studied at the center of Islamic studies in Mecca.

The strategy was also carried out by Kiai Șālih Darat in addressing the differences in the initial determination of Ramadan in Semarang. His ideas show that there is a modern Islamic intellectual tradition that is being built. $\mathrm{He}$

${ }^{79}$ M.C. Ricklefs, Sejarah Indonesia Modern (Yogyakarta: Gadjah Mada University Press, 1998), 255.

${ }^{80}$ Shokheh, Gerakan Keagamaan dan Perubahan Sosial; Dakwah Islam dan Misi Katolik di Semarang 1890-194, 103. 
can be said to be a pioneer in the formation of the Dugderan tradition. The substance of this tradition is delivering the results of the trial of the initial determination of Ramadan conducted by astronomers, scholars, habaib and umara. The aim is to unify the differences in the initial designation of Ramadan among the people. An idea which is the result of dialectics between Falak Science and the socio-cultural community of Semarang. At that time, the social conditions of the people of Semarang had experienced differences in the initial determination of Ramadlan to have an impact on differences in the determination of the Eid al-Fitr. This can be traced from the process when Kiai Saalih Darat studied in several places in Java, and when he studied at the center of Islamic studies in Mecca.

\section{Conclusion}

Kiai Sălih Darat was one of the 19th century Nusantara scholars who was productive in writing many books. The number of Kiai Sāliḥ Darat's works is believed to be around 40 books, but currently only 14 (fourteen) books are found. Of all his works, Kiai Sālih Darat is better known as a scholar who is an expert in the field of Sufism. Until Kiai Șālih Darat was mentioned in the sanad of Shaykh Yāsīn al-Fadanī as al-Ghazālī al-Shaghīr (little al-Ghazālī). Nevertheless, Kiai Sālih Darat was also positioned as a scholar who was an expert in falak science. Even in the salaf generation (early) the Nusantara clerics who were experts in the field of reckoning. The salaf generation of Indonesian falak experts are Shaykh Ahmad Khațib Minangkabau (18551916), Shaykh Ṭāhir Jamāluddīn Al-Azhārī Al-Falakī, Ahmmad Rifā'ī Kalisalak, Kiai Șāliḥ Darat and Muhammad Arshad Al-Banjarī.

Kiai Sălih Darat's expertise in the field of falak knowledge was obtained from Kiai 'Abd al-Hādī ibn Ba'ūnī, a Mufti in Semarang. While Kiai Abdul 'Abd al-Hādī ibn Ba'ūnī studied Falak with Kiai Muhammad Nīr al-Sepatonī alSamārānī. Even according to Muchoyyar HS's research, Kiai Șāliḥ Darat also studied Falak directly from Kiai Muhammad Nur al-Sepatoni. In addition, Kiai Sālih Darat also received lessons in falak during his studies in Mecca. Because in the 19th century in Mecca the halaqah of scientific activities and intellectual traditions made the work in the field of Falak sciences develop. One of Kiai Sālih Darat's teachers in Mecca who is an expert in the field of Falak Science is Shaykh Ahmad ibn Zaynī Daḥlān (1231-1304 H / 1817-1886 AD) who has a work in the field of falak science entitled Al-Mukhtașar fi Ma'rifah al-Sinin wa al-Rub'al-Mushtahir. 
The main idea of Kiai Șălih Darat is when uniting the differences in determining the beginning of the month of Ramadan. The activity was carried out by holding a discussion at Kauman Semarang Mosque which involved the elements of government, scholars and haba'ib. While the community was gathered in the square in front of the Kauman Mosque in Semarang, by displaying a unique icon, which is called as Warak Ngendok. When the results of the trial had been decided, the Regent of Semarang delivered the results of the deliberations in front of the people who had gathered. The tradition of the Ngarakok Warak procession is named as the Dugderan tradition and is still preserved to this day.[a]

\section{BIBLIOGRAPHY}

Ahmad Fauzi Ilyas. 'Tradisi Ilmiah Ulama Falak Haramian Akhir Abad 19 M Dan Awal Abas 20 M (Profil Syaikh Muhammad Zein (W. 1388/1967) Dan Kontribusinya Dalam Ilmu Falak)'. Al-Marshad: Jurnal Astronomi Islam dan Ilmu-Ilmu Berkaitan 1, no. 1 (2015).

Al-Fadanī, Syaikh Muhammad Yāsīn bin 'Īsā. Al-'Iqd Al-Farīd Min AlJawāhir Al-Asānid,. Surabaya: Dār al-Saqaf, n.d.

—_- Al-Wāfi Bi Dhayl Tadhkah Al-Mașhafí. Lebanon: Dār al-Bashīr, 2008.

Al-Falimbānī, Muḥammad Mukhtāruddīn. Bulūgh Al-Amānī. Beirut: Dār al-Dutaybah, 1988.

Al-Tarmasī, Syaikh Maḥ̂uz. Kifāyah Al-Mustafíd Limā 'alā Min Al-Asānid. Lebanon: Dār al-Bashā’ir al-Islāmiyah, n.d.

Azhari, Susiknan. Ensiklopedi Hisab Rukyat. Yogyakarta: Pustaka Pelajar, 2008.

- - Ilmu Falak; Perjumpaan Khazanah Islam Dan Sains Modern. Yogyakarta: Suara Muhammadiyah, 2007.

Aziz, Akhmad Luthfi. 'Internalisasi Pemikiran KH. Muhammad Sholeh Darat Di Komunitas Pecintanya: Perspektif Sosiologi Pengetahuan'. Living Islam: Journal of Islamic Discourses 1, no. 2 (November 28, 2018).

http://ejournal.uinsuka.ac.id/ushuluddin/li/article/view/1733.

Aziz, Munawir. 'Produksi Wacana Syiar Islam Dalam Kitab Pegon Kiai Saleh Darat Semarang Dan Kiai Bisri Musthofa Rembang'. 
Afkaruna: Indonesian Interdisciplinary Journal of Islamic Studies 9, no. 2 (2017).

Azra, Azyumardi. Historiografi Islam Kontemporer; Wacana, Aktualitas Dan Aktor Sejarah. Jakarta: Gramedia, 2002.

Bizawie, Zainul Milal. Masterpiece Islam Nusantara. Jakarta: Pustaka Kompas, 2016.

Dzahir, Abu Malikus Salih. Sejarah Dan Perjuangan Kyai Muhammad Shaleh Darat Semarang. Semarang: Panitia Haul Kyai Shaleh Darat Semarang, 2012.

El-Seha, Mastuki HS dan Ishom. Intelektualisme Pesantren. Jakarta: Diva Pustaka, 2004.

Jayusman. 'Pemikiran Ilmu Falak Kyai Noor Ahmad SS'. IAIN Walisongo Semarang, 2013.

- - - 'Sejarah Perkembangan Ilmu Falak Sebuah Ilustrasi Paradoks Perkembangan Sains Dalam Islam'. Al-Marshad: Jurnal Astronomi Islam dan Ilmu-Ilmu Berkaitan 1, no. 1 (February 24, 2017).

Kartodirdjo, Sartono. 'Metode Penggunaan Bahan Dokumenter'. In Metode-Metode Penelitian Masyarakat, edited by Koentjaraningrat. Jakarta: Gramedia, 1977.

Maryani. 'Studi Analisis Metode Penentuan Waktu Salat Dalam Kitab AdDurus Al-Falakiyyah Karya Ma'sum Bin Ali'. IAIN Walisongo Semarang, 2010.

Masrur, Mohammad. 'Kyai Soleh Darat, Faid Al-Rahman, Dan RA. Kartini'. At-Taqaddum 4, no. 1 (2016): 21-38. http://journal.walisongo.ac.id/index.php/attaqaddum/article/vie $\mathrm{w} / 725$.

Masruroh. 'Studi Analisis Hisab Awal Bulan Kamariah Menurut KH. Muhammad Hasan Asy'ari Dalam Kitab Muntaha Nataij Al-Aqwal'. Institute Agama Islam Negeri Walisongo Semarang, 2011.

Masyhuri, Aziz. 99 Kyai Kharismatik Indonesia. Yogyakarta: Kutub, 2008.

Mubit, Rizal. 'Hisab Awal Waktu Salat Dalam Kitab "al-Khulashah Fi AlAwqat Al-Syar'iyyah Bi Al-Lugharitmiyyah" Karya Muhammad Khumaidi Jazry'. Al-Marshad: Jurnal Astronomi Islam dan Ilmu-Ilmu Berkaitan 2, no. 1 (December 30, 2016): 64-82.

Muhammad, Djawahir. Semarang Sepanjang Jalan Kenangan. Edited by Djawahir Muhammad. Semarang: Penerbit Aktor Studio, 1995. 
Munfaridah, Imroatul. 'Studi Kritik Terhadap Penentuan Arah Kiblat Dan Awal Bulan Qamariyah Pemikiran KH. Ahmad Dahlan'. Institut Agama Islam Negeri Walisongo Semarang, 2011.

Munir, Ghazali. Tuhan, Manusia Dan Alam Dalam Pemikiran Kalam Muhammad Salih as-Samarani. Semarang: Rasail, 2008.

Muspriyanto, Edy, and Saifur. Semarang Tempo Doeloe; Meretas Masa. Semarang: Terang Publishing, 2007.

Nasir, M. Rifa Jamaluddin. 'Pemikiran Hisab KH. Ma'shum Bin Ali AlMaskumambangi (Analisis Terhadap Kitab Badi'ah Al-Misal Fi Hisab Al-Sinin Wa Al-Hilal Tentang Hisab Al-Hilal)'. IAIN Walisongo Semarang, 2010.

Nata, Abuddin. Sejarah Sosial Inteletual Islam Dan Institusi Pendidikannya. Jakarta: RajaGrafindo Persada, 2012.

Penulis, Tim. Intelektualisme Pesantren: Potret Tokoh Dan Cakrawala Pemikiran Di Era Perkembangan Pesantren. Jakarta: Diva Pesantren, 2006.

Ricklefs, M.C. Sejarah Indonesia Modern. Yogyakarta: Gadjah Mada University Press, 1998.

Sahal, Hamzah. 'Ihwal Warak Ngendok Dan Dugderan'. NU Online. Last modified 2011. Accessed December 27, 2019. https://www.nu.or.id/post/read/33261/ihwal-warak-ngendokdan-dugderan.

Salam, Abd. Dr. H. Sriyatin Shodiq, MA, Doktor 'Ilmu Falak'; Sebuah Apresiasi Dari Seorang Senior, Teman Dan Murid, 2012.

Shokheh, Mukhamad. Gerakan Keagamaan Dan Perubahan Sosial; Dakwah Islam Dan Misi Katolik Di Semarang 1890-194. Pati: Kireinara, 2014.

Șiddīq, 'Amal Ramaḍān 'Abd al-Hakīm. Al-Hayah Al-'Ilmiyyah Fī Makkah 1115-1334 H / 1703 - 1916 M. Mekah: Jam'iyyah Umm al-Qurā, 2006.

Siraj, Said Aqil. 'Kata Pengantar'. In Syarah Hikam: KH. Sholeh Darat, Maha Guru Ulama Besar Nusantara, edited by Miftahul Ulum. Depok: Sahifa, 2016.

Steenbrink, Karel A. Pesantren Madrasah Sekolah Pendidikan Islam Dalam Kurun Modern. Edited by Karel A. Steenbrink and Abdurrahman. Jakarta: LP3S, 1991. 
Supramono. 'Makna Warak Ngendog Dalam Tradisi Ritual Dugderan Di Kota Semarang'. Universitas Negeri Semarang, 2007.

Triyanto, Nur Rokhmat, and Mujiyono -. 'Warak Ngendhog: Simbol Akulturasi Budaya Pada Karya Seni Rupa'. Komunitas: International Journal of Indonesian Society and Culture 5, no. 2 (February 18, 2014).

Ulum, Amirul. KH Muhammad Sholeh Darat Al-Samarani; Mahaguru Ulama Nusantara. Yogyakarta: Global Press, 2016.

Wahid, Abdurrahman. 'Penelitian Kitab Kuning'. Harian Kompas, 1982.

Zubair, KH. Maimoen. Tarājim Mashāyikh Al-Ma'āhid Al-Dīniyyah Bi Sarang Al-Qudamā'. Rembang: Maktabah Al-Anwar, n.d. 
Muhamad Zainal Mawahib, Maskur Rosyid, Muhammad Syarif Hidayat 